\title{
Upaya meningkatkan kompetensi guru dalam menyusun rencana pelaksanaan pembelajaran melalui workshop dan bimbingan berkelanjutan
}

\author{
Welli Kurnia*) \\ SDN 19 Tanjung Durian Kec. Bayang
}

\begin{tabular}{|c|c|}
\hline Article Info & ABSTRACT \\
\hline & Penelitian Tindakan Sekolah dilaksanakan di UPT SDN 19 Tanjung Durian \\
\hline Article history: & Kecamatan Bayang Kabupaten Pesisir Selatan yang merupakan sekolah \\
\hline Received Jun $17^{\text {th }}, 2021$ & binaan peneliti sebagai kepala sekolah, terdiri atas dua puluh guru kelas dan \\
\hline Revised Jul $28^{\text {th }}, 2021$ & guru mata pelajaran sebagai sampel, dan dilaksanakan dalam dua siklus. $\mathrm{Ke}$ \\
\hline Accepted Aug 27 $7^{\text {th }}, 2021$ & $\begin{array}{l}\text { dua puluh orang guru tersebut menunjukkan sikap yang baik dan termotivasi } \\
\text { dalam menyusun RPP dengan lengkap. Hal ini peneliti ketahui dari hasil }\end{array}$ \\
\hline & $\begin{array}{l}\text { RPP. Pada siklus pertama semua guru (dua puluh orang) mencantumkan } \\
\text { penilaian hasil belajar dalam RPP-nya meskipun sub-sub komponennya }\end{array}$ \\
\hline Kompetensi guru & (teknik, bentuk instrumen, soal), pedoman penskoran, dan kunci jawabannya \\
\hline $\mathrm{RPP}$ & kurang lengkap. Jika dipersentasekan, $45 \%$. tiga orang guru masing-masing \\
\hline Workshop & mendapat skor 1 dan tiga guru masing-masing mendapat skor 2 (cukup baik), \\
\hline Bimbingan berkelanjutan & $\begin{array}{l}\text { lima orang mendapat skor } 3 \text { (baik), dan tiga orang mendapat skor } 4 \text { (sangat } \\
\text { baik). Pada siklus kedua kedua puluh guru tersebut mencantumkan penilaian } \\
\text { hasil belajar dalam RPP-nya meskipun ada guru yang masih keliru dalam } \\
\text { menentukan teknik dan bentuk penilaiannya. Tiga orang mendapat skor } \\
\text { 2(cukup baik), Tujuh orang mendapat skor } 3 \text { (baik) dan empat orang mendapat } \\
\text { skor } 4 \text { (sangat baik). Jika dipersentasekan, } 55 \% \text {, terjadi peningkatan } 10 \% \text { dari } \\
\text { siklus I. Berdasarkan pembahasan di atas terjadi peningkatan kompetensi guru } \\
\text { dalam menyusun RPP. Pada siklus I nilai rata-rata komponen RPP 71\%, pada } \\
\text { siklus II nilai rata-rata komponen RPP 91\%, terjadi peningkatan } \mathbf{2 0} \% \text {. }\end{array}$ \\
\hline
\end{tabular}

(C) 2021 The Authors. Published by IICET.

This is an open access article under the CC BY-NC-SA license (https://creativecommons.org/licenses/by-nc-sa/4.0)

\section{Corresponding Author:}

Welli Kurnia,

SDN 19 Tanjung Durian Kec. Bayang

Email: welikurnia@gmail.com

\section{Pendahuluan}

Pendidikan nasional yang berdasarkan pancasila dan Undang Undang Dasar Negara Republik Indonesia Tahun 1945 berfungsi mengembangkan kemampuan dan membentuk watak serta peradaban bangsa yang bermartabat dalam rangka mencerdaskan kehidupan bangsa, bertujuan untuk mengembangkan potensi peserta didik agar menjadi manusia yang beriman dan bertakwa kepada Tuhan Yang Maha Esa, beraklak mulia, sehat, berilmu, cakap, kreatif mandiri dan menjadi warga negara yang demokratis serta bertanggung jawab. Untuk mengemban fungsi tersebut pemerintah menyelenggarakan suatu sistem pendidikan nasional sebagaimana tercantum dalam Undang Undang Nomor 20 Tahun 2003 tentang Sistem Pendidikan Nasional. Implementasi Undang-Undang Nomor 20 tahun 2003 dijabarkan kedalam sejumlah peraturan antara lain Peraturan Pemerintah Nomor 19 Tahun 2005 tentang Standar Nasional Pendidikan. Peraturan Pemerintah ini memberikan arahan tentang perlunya di susun dan dilaksanakan delapan standar nasional pendidikan, yaitu 
standar isi, standar proses, standar kompetensi lulusan, standar pendidik dan tenaga kependidikan, standar sarana dan prasarana, standar pengelolaan, standar pembiayaan dan standar penilaian pendidikan.

Semua itu terkait dengan kondisi di lapangan bahwa : (a) tidak semua guru UPT SDN 19 Tanjung Durian Kec. Bayang Kecamatan Bayang, terutama yang berstatus honorer, berkesempatan mengikuti work shop atau diklat KTSP, (b) jarangnya kegiatan KKG yang khusus membahas RPP pelajaran.

Kondisi yang demikian menjadikan persepsi guru UPT SDN 19 Tanjung Durian Kec. Bayang Kecamatan Bayang mengenai RPP yang harus disusunnya sebelum melaksanakan pembelajaran di kelas, studio atau tempat belajar lainnya menjadi beragam dan kurang komprehensif. Misalnya masih terdapat guru yang belum memahami komponen minimal RPP, apalagi mengenai RPP yang komponennya lengkap dan sistematis. Kekurangan ini tentu saja akan menghambat upaya peningkatan mutu proses dan hasil pembelajaran, karena RPP-nya tidak disusun dengan baik. Padahal, keberhasilan sebuah kegiatan, lebih dari $50 \%$ ditentukan oleh perencanaan yang baik, sehingga keberhasilan pembelajaran pun amat ditentukan oleh RPP yang disusun guru.

Dengan memahami kondisi yang demikian, maka dipandang perlu adanya upaya untuk meningkatkan kemampuan atau kompetensi guru UPT SDN 19 Tanjung Durian Kec. Bayang Kecamatan Bayang dalam menyusun RPP yang lengkap dan sistematis. Berdasarkan pada fenomena tersebut di atas, maka penulis akan melakukan penelitian tentang "Upaya meningkatkan kompetensi guru dalam menyusun Rencana Pelaksanaan Pembelajaran (RPP) melalui work shop dan bimbingan berkelanjutan di UPT SDN 19 Tanjung Durian Kec. Bayang Kecamatan Bayang"

\section{Metode}

Penelitian ini berbentuk Penelitian Tindakan Sekolah (School Action Research), yaitu sebuah penelitian yang merupakan kerjasama antara peneliti dan guru, dalam meningkatkan kemampuan guru agar menjadi lebih baik dalam menyusun rencana pelaksanaan pembelajaran.

Penelitian ini bertujuan untuk mendeskripsikan kesulitan-kesulitan yang dialami oleh guru dalam menyusun RPP. Selanjutnya peneliti memberikan alternatif atau usaha guna meningkatkan kemampuan guru dalam membuat rencana pelaksanaan pembelajaran. Penelitian ini dilakukan di UPT SDN 19 Tanjung Durian Kec. Bayang Kecamatan Bayang. PTS ini dilaksanakan pada semester satu tahun 2020 selama kurang lebih dua bulan mulai Agustus sampai dengan Oktober 2020. Penelitian Tindakan Sekolah dilaksanakan melalui dua siklus untuk melihat peningkatan kompetensi guru dalam menyusun Rencana Pelaksanaan Pembelajaran (RPP ). Subjek penelitian ini adalah guru-guru UPT SDN 19 Tanjung Durian Kec. Bayang Kecamatan Bayang, yang jumlahnya 20 orang guru. Teknik pengumpulan data dalam penelitian ini adalah wawancara, observasi, dan diskusi; a)wawancara dipergunakan untuk mendapatkan data atau informasi tentang pemahaman guru terhadap RPP, b) Observasi dipergunakan untuk mengumpulkan data dan mengetahui kompetensi guru dalam menyusun Rencana Pelaksanaan Pembelajaran dengan lengkap, c) Diskusi dilakukan antara peneliti dengan guru. Alat pengumpulan data dalam PTS ini sebagai berikut; a) Wawancara menggunakan panduan wawancara untuk mengetahui kemampuan awal yang dimiliki guru tentang Rencana Pelaksanaan Pembelajaran, b) Wawancara menggunakan panduan wawancara untuk mengetahui kemampuan awal yang dimiliki guru tentang Rencana Pelaksanaan Pembelajaran, c) Diskusi dilakukan dengan maksud untuk sharing pendapat antara peneliti dengan guru.

Rencana pelaksanaan dilakukan dalam dua siklus yaitu:

1. Siklus Pertama (Siklus I)

a. Peneliti merencanakan tindakan pada siklus I (membuat format/instrumen wawancara, penilaian RPP, rekapitulasi hasil penyusunan RPP).

b. Peneliti memberi kesempatan kepada guru untuk mengemukakan kesulitan atau hambatan dalam menyusun Rencana Pelaksanaan Pembelajaran.

c. Peneliti menjelaskan kepada guru tentang pentingnya RPP dibuat secara lengkap.

d. Peneliti memberikan work shop dalam pengembangan RPP.

e. Peneliti melakukan observasi/pengamatan terhadap RPP yang telah dibuat guru.

f. Peneliti melakukan revisi atau perbaikan penyusunan rencana pelaksanaan pembelajaran yang lengkap.

g. Peneliti dan guru melakukan refleksi. 
a. Peneiti merencanakan tindakan pada siklus II yang mendasarkan pada revisi/perbaikan pada siklus I, seperti menugasi guru menyusun RPP yang kedua, mengumpulkan, dan melakukan pembimbingan penyusunan RPP.

b. Peneliti melaksanakan tindakan sesuai dengan rencana pada siklus II.

c. Peneliti melakukan observasi/pengamatan terhadap RPP yang telah dibuat guru.

d. Peneliti melakukan perbaikan atau revisi penyusunan RPP.

e. Peneliti dan guru melakukan refleksi.

Peneliti mengharapkan secara rinci indikator pencapaian hasil paling rendah $80 \%$ guru membuat kesebelas komponen Rencana Pelaksanaan Pembelajaran sebagai berikut:

1. Komponen identitas mata pelajaran diharapkan ketercapaiannya $100 \%$.

2. Komponen standar kompetensi diharapkan ketercapaiannya $100 \%$.

3. Komponen kompetensi dasar diharapkan ketercapaiannya $100 \%$.

4. Komponen indikator pencapaian kompetensi diharapkan ketercapaiannya $80 \%$.

5. Komponen tujuan pembelajaran diharapkan ketercapaiannya $75 \%$.

6. Komponen materi pembelajaran diharapkan kecercapaian $100 \%$.

7. Komponen alokasi waktu diharapkan ketercapaiannya $100 \%$.

8. Komponen metode pembelajaran diharapkan kecercapaiannya $75 \%$.

9. Komponen langkah-langkah kegiatan pembelajaran diharapkan ketercapaiannya $75 \%$.

10. Komponen sumber belajar diharapkan ketercapaiannya $75 \%$.

11. Komponen penilaian (soal, pedoman penskoran, kunci jawaban) diharapkan ketercapaiannya $75 \%$.

\section{Hasil dan Pembahasan}

Berdasarkan hasil observasi peneliti terhadap lima RPP yang dibuat guru (khusus pada siklus I), diperoleh informasi/data bahwa masih ada guru yang tidak melengkapi RPP-nya dengan komponen dan subsubkomponen RPP tertentu, misalnya komponen indikator dan penilaian hasil belajar (pedoman penskoran dan kunci jawaban). Rumusan kegiatan siswa pada komponen langkah-langkah kegiatan pembelajaran masih kurang tajam, interaktif, inspiratif, menantang, dan sistematis.

Dilihat dari segi kompetensi guru, terjadi peningkatan dalam menyusun Rencana Pelaksanaan Pembelajaran dari siklus ke siklus . Hal itu dapat dilihat pada lampiran Rekapitulasi Hasil Penyusunan RPP dari Siklus ke Siklus (Lampiran 4).

\section{Siklus I (Pertama)}

Siklus pertama terdiri dari empat tahap yakni: (1) perencanaan, (2) pelaksanaan, (3) observasi, dan (4) refleksi seperti berikut ini.

1. Perencanaan ( Planning )

a. Membuat lembar wawancara

b. Membuat format/instrumen penilaian RPP

c. Membuat format rekapitulasi hasil penyusunan RPP siklus I dan II

d. Membuat format rekapitulasi hasil penyusunan RPP dari siklus ke siklus

\section{Pelaksanaan (Acting)}

Pada saat awal siklus pertama indikator pencapaian hasil dari setiap komponen RPP belum sesuai/tercapai seperti rencana/keinginan peneliti. Hal itu dibuktikan dengan masih adanya komponen RPP yang belum dibuat secara lengkap oleh guru. Sebelas komponen RPP yakni: 1) identitas mata pelajaran, 2) standar kompetensi, 3) kompetensi dasar, 4) indikator pencapaian kompetensi, 5) tujuan pembelajaran, 6) materi ajar, 7) alokasi waktu, 8) metode pembelajaran, 9) langkah-langkah kegiatan pembelajaran, 10) sumber belajar, 11) penilaiaan hasil belajar ( soal, pedoman penskoran, dan kunci jawaban). Hasil observasi pada siklus kesatu dapat dideskripsikan berikut ini:

Observasi dilaksanakan, 30 Agustus s.d 3 september 2018, terhadap Dua Puluh orang guru. Semuanya menyusun RPP, tapi masih ada guru yang belum melengkapi RPP-nya baik dengan komponen maupun sub-sub komponen RPP tertentu. Satu orang tidak melengkapi RPP-nya dengan komponen indikator pencapaian kompetensi. Untuk komponen penilaian hasil belajar, dapat dikemukakan sebagai berikut.

Dua orang tidak melengkapinya dengan teknik dan bentuk instrumen.

- Empat orang tidak melengkapinya dengan teknik, bentuk instumen, soal, pedoman penskoran, dan kunci jawaban.

- Dua orang tidak melengkapinya dengan teknik, pedoman penskoran, dan kunci jawaban.

- Tiga orang tidak melengkapinya dengan soal, pedoman penskoran, dan kunci jawaban. 
- Satu orang tidak melengkapinya dengan pedoman penskoran dan kunci jawaban. Selanjutnya mereka dibimbing dan disarankan untuk melengkapinya.

\section{Siklus II (Kedua)}

Siklus kedua juga terdiri dari empat tahap yakni: (1) perencanaan, (2) pelaksanaan, (3) observasi, dan (4) refleksi. Hasil observasi pada siklus kedua dapat dideskripsikan berikut ini:

Observasi dilaksanakan 27-30 September 2020, terhadap dua puluh orang guru. Semuanya menyusun RPP, tapi masih ada guru yang keliru dalam menentukan kegiatan siswa dalam langkah-langkah kegiatan pembelajaran dan metode pembelajaran, serta tidak memilah/ menguraikan materi pembelajaran dalam subsub materi. Untuk komponen penilaian hasil belajar, dapat dikemukakan sebagai berikut.

- Tujuh orang keliru dalam menentukan teknik dan bentuk instrumennya.

- Tiga orang keliru dalam menentukan bentuk instrumen berdasarkan teknik penilaian yang dipilih.

- Empat orang kurang jelas dalam menentukan pedoman penskoran.

- Satu orang tidak menuliskan rumus perolehan nilai siswa.

- Selanjutnya mereka dibimbing dan disarankan untuk melengkapinya.

Penelitian Tindakan Sekolah dilaksanakan di UPT SDN 19 Tanjung Durian Kec. Bayang Kecamatan Bayang Kabupaten Pesisir Selatan yang merupakan sekolah binaan peneliti sebagai kepala sekolah, terdiri atas dua puluh guru kelas dan guru mata pelajaran sebagai sampel, dan dilaksanakan dalam dua siklus. Ke dua puluh orang guru tersebut menunjukkan sikap yang baik dan termotivasi dalam menyusun RPP dengan lengkap. Hal ini peneliti ketahui dari hasil pengamatan pada saat melakukan wawancara dan bimbingan penyusunan RPP. Selanjutnya dilihat dari kompetensi guru dalam menyusun RPP, terjadi peningkatan dari siklus ke siklus.

\section{Komponen Identitas Mata Pelajaran}

Pada siklus pertama semua guru (dua puluh orang guru) mencantumkan identitas mata pelajaran dalam RPP-nya (melengkapi RPP-nya dengan identitas mata pelajaran). Jika dipersentasekan, 84\%. Dua belas orang guru mendapat skor 3 (baik) dan dua orang mendapat skor 4 (sangat baik). Pada siklus kedua dua puluh guru tersebut mencantumkan identitas mata pelajaran dalam RPP-nya. Semuanya mendapat skor 4 (sangat baik). Jika dipersentasekan, 100\%, terjadi peningkatan 16\% dari siklus I.

\section{Komponen Standar Kompetensi}

Pada siklus pertama semua guru (dua puluh orang) mencantumkan standar kompetensi dalam RPP-nya (melengkapi RPP-nya dengan standar kompetensi), jika di persentasekan 100\%. Pada siklus kedua kedua puluh orang guru tersebut mencantumkan standar kompetensi dalam RPP-nya jika di persentasekan, $100 \%$. Baik pada siklus 1 atau siklus dua seluruh guru telah mencantumkan standar kompetensi.

\section{Komponen Kompetensi Dasar}

Pada siklus pertama semua guru (dua puluh orang) mencantumkan kompetensi dasar dalam RPP-nya (melengkapi RPP-nya dengan kompetensi dasar). Jika dipersentasekan, $81 \%$. Satu orang guru mendapat skor 1 (kurang baik), dua orang guru masing-masing mendapat skor 2 (cukup baik), dan dua orang guru masing-masing mendapat skor 3 (baik). Delapan guru mendapat skor 4 (sangat baik). Pada siklus kedua kedua puluh orang guru tersebut mencantumkan kompetensi dasar dalam RPP-nya. Dua mendapat skor 3 (baik) dan sebelas orang mendapat skor 4 (sangat baik). Jika dipersentasekan, 93\%, terjadi peningkatan $12 \%$ dari siklus I.

\section{Komponen Indikator Pencapaian Kompetensi}

Pada siklus pertama dua puluh orang guru mencantumkan indikator pencapaian kompetensi dalam RPPnya (melengkapi RPP-nya dengan indikator pencapaian kompetensi). Jika dipersentasekan, 86\%. Dua orang guru masing-masing mendapat skor 1 dan 2 (kurang baik dan cukup baik). Delapan orang guru mendapat skor 3 (baik). Dua orang guru mendapat skor 4 (sangat baik).Pada siklus kedua 2 guru tersebut mencantumkan indikator pencapaian kompetensi dalam RPP-nya. Enam orang mendapat skor 3 (baik) dan enam orang mendapat skor 4 (sangat baik). Jika dipersentasekan, 93\%, terjadi peningkatan $7 \%$ dari siklus I.

\section{Komponen Tujuan Pembelajaran}

Pada siklus pertama semua guru (dua puluh orang) mencantumkan tujuan pembelajaran dalam RPP-nya (melengkapi RPP-nya dengan tujuan pembelajaran). Jika dipersentasekan, 55\%. tiga orang guru mendapat skor 1 (kurang baik), dua orang mendapat skor 2 (cukup baik), dan tiga orang mendapat skor 3 (baik) dan enam orang guru mendapat skor 4(sangat baik). Pada siklus kedua kedua puluh guru tersebut 
mencantumkan tujuan pembelajaran dalam RPP-nya. Lima orang mendapat skor 7 (baik) dan dua puluh orang mendapat skor 4 (sangat baik). Jika dipersentasekan, 93\%, terjadi peningkatan 38\% dari siklus I.

\section{Komponen Materi Ajar}

Pada siklus pertama semua guru (dua puluh orang) mencantumkan materi ajar dalam RPP-nya (melengkapi RPP-nya dengan materi ajar). Jika dipersentasekan, $62 \%$. satu orang guru masing-masing mendapat skor 1 (kurang baik) dan tiga orang mendapat skor 2 (cukup baik), lima orang mendapat skor 3 (baik). lima orang guru masing-masing mendapat skor 4 (sangat baik), dan Pada siklus kedua kedua puluh guru tersebut mencantumkan materi ajar dalam RPP-nya. sepuluh orang guru mendapat skor 3 (baik) dan empat orang guru mendapat skor 4 (sangat baik). Jika dipersentasekan, 89\%, terjadi peningkatan $27 \%$ dari siklus I.

\section{Komponen Alokasi Waktu}

Pada siklus pertama semua guru (dua puluh orang) mencantumkan alokasi waktu dalam RPP-nya (melengkapi RPP-nya dengan alokasi waktu). Semuanya mendapat skor 4 (sangat baik). Jika dipersentasekan, $100 \%$. Pada siklus kedua kedua puluh guru tersebut mencantumkan alokasi waktu dalam RPP-nya. Semuanya mendapat skor 4 (sangat baik). Jika dipersentasekan, 100\%.

\section{Komponen Metode Pembelajaran}

Pada siklus pertama semua guru (dua puluh orang guru) mencantumkan metode pembelajaran dalam RPP-nya (melengkapi RPP-nya dengan metode pembelajaran). Jika dipersentasekan, 52\%. enam orang guru mendapat skor 2 (cukup baik), empat orang mendapat skor 3 (baik), dan empat orang mendapat skor 4 (sangat baik). Pada siklus kedua kedua puluh guru tersebut mencantumkan metode pembelajaran dalam RPP-nya. Satu orang mendapat skor 2 (cukup baik), sembilan orang mendapat skor 3 (baik), dan empat orang mendapat skor 4 (sangat baik). Jika dipersentasekan, 93\%, terjadi peningkatan $41 \%$ dari siklus I.

\section{Komponen Langkah-Langkah Kegiatan Pembelajaran}

Pada siklus pertama semua guru (dua puluh orang) mencantumkan langkah-langkah kegiatan pembelajaran dalam RPP-nya (melengkapi RPP-nya dengan langkah-langkah kegiatan pembelajaran). Jika dipersentasekan, 52\%. Empat orang guru mendapat skor 2 (cukup baik), sedangkan tujuh orang mendapat skor 3 (baik), tiga orang guru mendapat skor 4(sangat baik). Pada siklus kedua kedua puluh guru tersebut mencantumkan langkah-langkah kegiatan pembelajaran dalam RPP-nya. satu orang mendapat skor 2 (cukup baik) dan delapan belas orang mendapat skor 3 (baik). lima orang guru mendapat skor 4(sangat baik). Jika dipersentasekan, 89\%, terjadi peningkatan 37\% dari siklus I.

\section{Komponen Sumber Belajar}

Pada siklus pertama semua guru (dua puluh orang) mencantumkan sumber belajar dalam RPP-nya (melengkapi RPP-nya dengan sumber belajar). Jika dipersentasekan, 66\%. Dua orang guru mendapat skor 2 (cukup baik), delapan orang mendapat skor 3 (baik), empat orang guru mendapat skor 4 (sangat baik). Pada siklus kedua kedua puluh guru tersebut mencantumkan sumber belajar dalam RPP-nya. Dua orang mendapat skor 2 (cukup baik) dan enam mendapat skor 3 (baik), 6 orang guru mendapat skor 4(sangat baik). Jika dipersentasekan, 93\%, terjadi peningkatan 27\% dari siklus I.

\section{Komponen Penilaian Hasil Belajar}

Pada siklus pertama semua guru (dua puluh orang) mencantumkan penilaian hasil belajar dalam RPPnya meskipun sub-sub komponennya (teknik, bentuk instrumen, soal), pedoman penskoran, dan kunci jawabannya kurang lengkap. Jika dipersentasekan, 45\%. tiga orang guru masing-masing mendapat skor 1 dan tiga guru masing-masing mendapat skor 2 (cukup baik), lima orang mendapat skor 3 (baik), dan tiga orang mendapat skor 4 (sangat baik). Pada siklus kedua kedua puluh guru tersebut mencantumkan penilaian hasil belajar dalam RPP-nya meskipun ada guru yang masih keliru dalam menentukan teknik dan bentuk penilaiannya. Tiga orang mendapat skor 2(cukup baik), Tujuh orang mendapat skor 3 (baik) dan empat orang mendapat skor 4 (sangat baik). Jika dipersentasekan, $55 \%$, terjadi peningkatan $10 \%$ dari siklus I.

Berdasarkan pembahasan di atas terjadi peningkatan kompetensi guru dalam menyusun RPP. Pada siklus I nilai rata-rata komponen RPP 71\%, pada siklus II nilai rata-rata komponen RPP 91\%, terjadi peningkatan $20 \%$.

\section{Simpulan}


Berdasarkan hasil Penelitian Tinadakan Sekolah (PTS) dapat disimpulkan sebagai berikut: 1) Work shop dan bimbingan berkelanjutan dapat meningkatkan motivasi guru dalam menyusun RPP dengan lengkap. Guru menunjukkan keseriusan dalam memahami dan menyusun RPP apalagi setelah melaksanakan work shop mendapatkan bimbingan pengembangan/penyusunan RPP dari peneliti. Informasi ini peneliti peroleh dari hasil pengamatan pada saat mengadakan wawancara dan bimbingan pengembangan/penyusunan RPP kepada para guru; 2) Bimbingan berkelanjutan dapat meningkatkan kompetensi guru dalam menyusun RPP. Hal itu dapat dibuktikan dari hasil observasi / pengamatan yang memperlihatkan bahwa terjadi peningkatan kompetensi guru dalam menyusun RPP dari siklus ke siklus . Pada siklus I nilai rata-rata komponen RPP 71\% dan pada siklus II 91\%. Jadi, terjadi peningkatan 20\% dari siklus I.

\section{Referensi}

BSNP. (2007). Peraturan Menteri Pendidikan Nasional Republik Indonesia Nomor 16 Tahun 2007 Tentang Standar Kualifikasi Akademik dan Kompetensi Guru. Jakarta : BSNP.

Peraturan Menteri Pendidikan Nasional Republik Indonesia Nomor 41 Tahun 2007 Tentang Standar Proses untuk Satuan Pendidikan Dasar dan Menengah.

Peraturan Pemerintah Nomor 19 Tahun 2005 tentang Standar Nasional Pendidikan.

Undang-Undang Republik Indonesia Nomor 14 Tahun 2005 tentang Guru dan Dosen.

Undang-Undang Republik Indonesia Nomor 20 Tahun 2003 Tentang Sistem Pendidikan Nasional.

Depdiknas. (2008). Pedoman Penelitian Tindakan Sekolah (School Action Research) Peningkatan Kompetensi Supervisi Pengawas Sekolah SMA / SMK. Jakarta : Dirjen PMPTK.

Panitia Pelaksana Pendidikan dan Latihan Profesi Guru Rayon 10 Jawa Barat. (2009). Bahan Ajar Pendidikan dan Latihan Profesi Guru (PLPG), Pengawas. Bandung : Universitas Pendidikan Indonesia.

Asrori,Muhammad. ((2008). Penelitian Tindakan Kelas. CV. Wahana Prima, Bandung Terbuka.

Mulyasa, E., 2003. Kurikulum Berbasis Kompetensi: Konsep, Karakteristik, dan Implementasi. Bandung: PT Remaja Rosdakarya

Sudjana, H. Nana. (2009). Penelitian Tindakan Kepengawasan, Konsep dan Aplikasinya bagi Pengawas Sekolah. Jakarta : Binamitra Publishing. 